УДК 904 (477.73)

DOI: https://doi.org/10.33782/eminak2020.1(29).396

\title{
ПРИМІЩЕННЯ № 25 ГОРОДИЩА ДИКИЙ САД*
}

\author{
Кирило Горбенко ${ }^{1}$, Ігор Піструіл² \\ ${ }^{1}$ Миколаївський національний університет ім. В.О. Сухомлинського (Миколаїв, Україна) \\ e-mail: dikiysad1@gmail.com; ORCID: https://orcid.org/0000-0002-0510-3792 \\ 2 Одеський археологічний музей НАН України (Одеса, Україна) \\ e-mail: pistruiligor@ukr.net; ORCID: https://orcid.org/0000-0002-6193-1963
}

Розглядаються конструктивні особливості приміщення № 25, що розташовувалося на території «цитаделі» городища доби фінального бронзового віку Дикий Сад (кінещь 13-11 cm. до н.е.). Охарактеризовано архітектурну структуру та принципи будови приміщення, а також особливості внутрішнього заповнення ям. Проаналізовано матеріальні предмети (керамічний посуд, вироби з кістки, рогу, каменю, бронзи), що зафіксовано у культурному шарі. Найбільш знакові знахідки: роговий псалій, кременевий серп і кам'яні предмети антропоморфної форми.

Окремо аналізується саме кременевий серп, що є першою подібною знахідкою на території Дикого Саду. Пропонуються варіанти кріплення знаряддя в оправі та його використання.

Ключові слова: фінальний бронзовий вік, білозерська культура, городище Дикий Сад, матеріальні предмети, псалій, кременевий серп

Городище доби фінального бронзового віку Дикий Сад (кінець 13-11 ст. до н.е.) розташоване на високому плато в місці злиття річок Інгул і Південний Буг (історичний центр сучасного міста Миколаїв, роза вулиць Набережна та Артилерійська). Умовно Дикий Сад складається з трьох частин: огороджена ровом «Цитадель», «Передмістя» та «Посад», що розташовувався за зовнішнім ровом. Архітектурні споруди розташовувалися рядами уздовж річки Інгул та практично примикали один до одного, створюючи єдиний архітектурний комплекс (рис. 1). Регулярні археологічні дослідження на території Дикого Саду проводяться упродовж останніх тридцяти років ${ }^{1}$. За ці роки досліджено житлові, господарські та ритуально-культові об’єкти, накопичено сотні артефактів (керамічний посуд, бронзові, кістяні та кам'яні предмети), проведено комплексні аналізи археологічних матеріалів².

У 2019 р. археологічні дослідження проводилися у розкопі № 18, що розташований у південній частині «цитаделі» городища, між приміщенням № 4 і ровом $\left(200 \mathrm{M}^{2}\right)$. Рівень сучасної поверхні знаходиться на відмітці 20,40 м від рівня Балтійського моря. Верхнє заповнення - залишки будівельного сміття XX ст. та глинистих завалів стін. Основний матеріал (невиразні фрагменти керамічного посуду, кістки тварин і риби) знаходилися на рівні 20,00-19,80 м, вперемішку з вапняковим бутом. У східній частині розкопу зафіксовано приміщення № 25 (рис. 1).

\footnotetext{
* Стаття виконана у рамках наукової теми № 0118U003394.

1 Горбенко К.В. Укріплене поселення (городище) епохи фінальної бронзи Дикий Сад у місті Миколаєві // Краєзнавство. Науковий журнал. 2018. № 1 (102). С. 6-20.

2 Горбенко К.В, Гошко Т.Ю. Металеві вироби з поселення Дикий Сад // Археологія. 2010. № 1. С. 97-111; Горбенко К.В., Пашкевич Г.О. Палеоетноботанічні дослідження на території городища Дикий Сад // Емінак: науковий щоквартальник. 2010. № 1-4 (5) (січень-грудень). С. 5-19.
} 


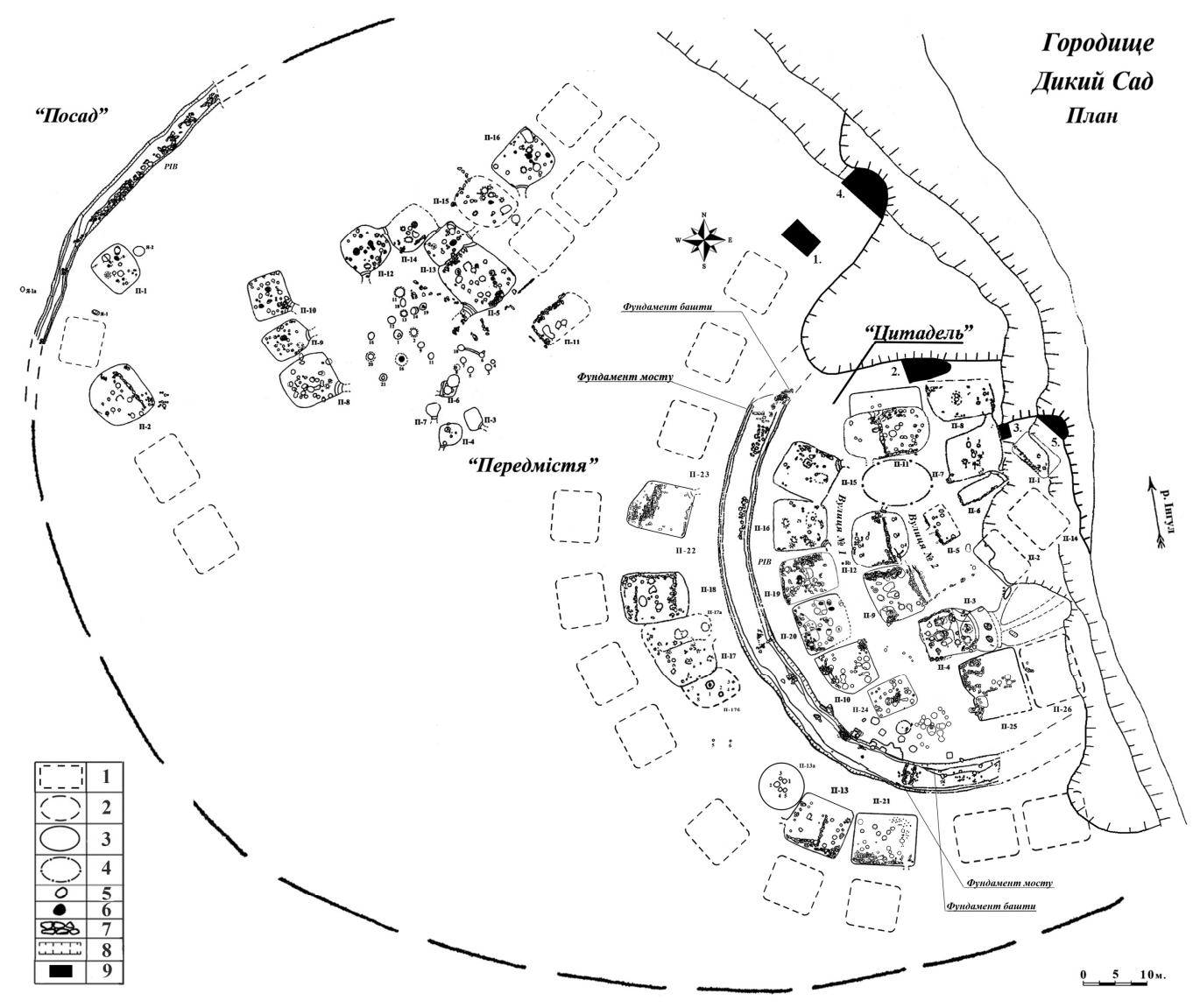

Рис. 1. План городища Дикий Сад

1 - межі ймовірних об'єктів; 2 - межі городища; 3 - контури приміщень; 4 - центральна площа; 5 - ями; 6 - вогнища; 7 - кам'яні кладки; 8 - рів; 9 - контури розкопів 1956 року.

Метою дослідження $є$ характеристика структури та заповнення ям приміщення № 25, статистична характеристика зафіксованих матеріальних предметів, а також аналіз кременевого серпа, що є першою подібною знахідкою на території городища.

Приміщення № 25 мало у плані прямокутну форму та було орієнтовано за віссю Пн-Зх-Пд-Сх. (розміри 9,5×9,0 м). Вихід материкової глини: у північно-західній частині зафіксовано на відмітці 19,83 м; у західній частині - 19,75 м; у південній частині, біля входу - 19,69 м. Приміщення складається з двох частин - основної частини (розмір - 8,0×9,0 м) та прямокутної прибудови у північній частині (розміри 3,5×1,5 м, заглибленість 0,36 м від рівня виходу материкового грунту).

Основна частина мала кам'яну перегородку довжиною 2,5 м (збереглася частково), що витягнулася з південного-заходу на північний-схід. Заглиблення основної частини приміщення в материк коливається від 0,32 м у північній до 1,04 м у південній частині. Необхідно відмітити, що більшість південної частини приміщення знищено траншеєю другої половини XX ст.

На відмітці 19,80 м проявилася пляма темного кольору (основне заповнення приміщення). Основний матеріал знаходився практично у нижній частині заповнення (північна частина - 19,75-19,32 м; південна частина - 19,30-19,05 м). 


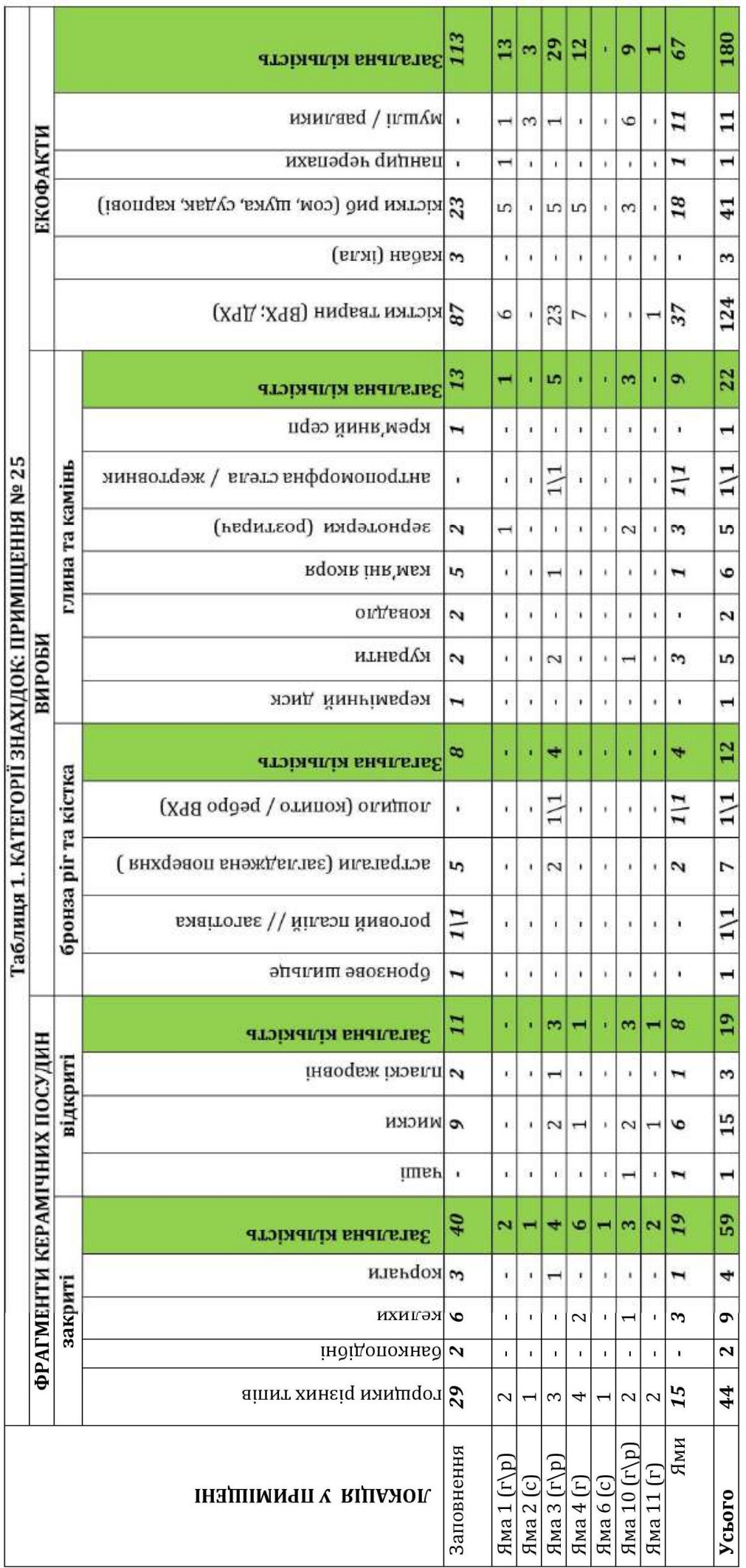

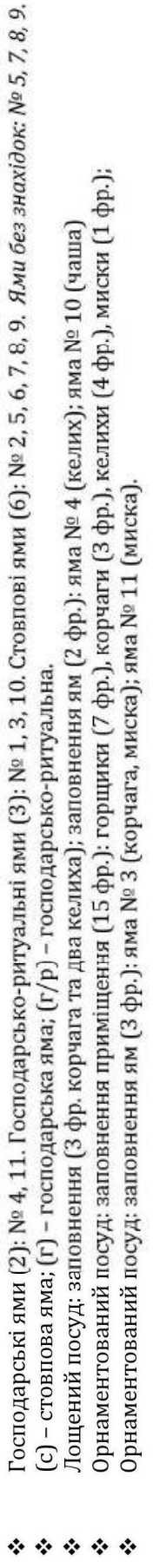

Eminak, 2020, 1 (29) 

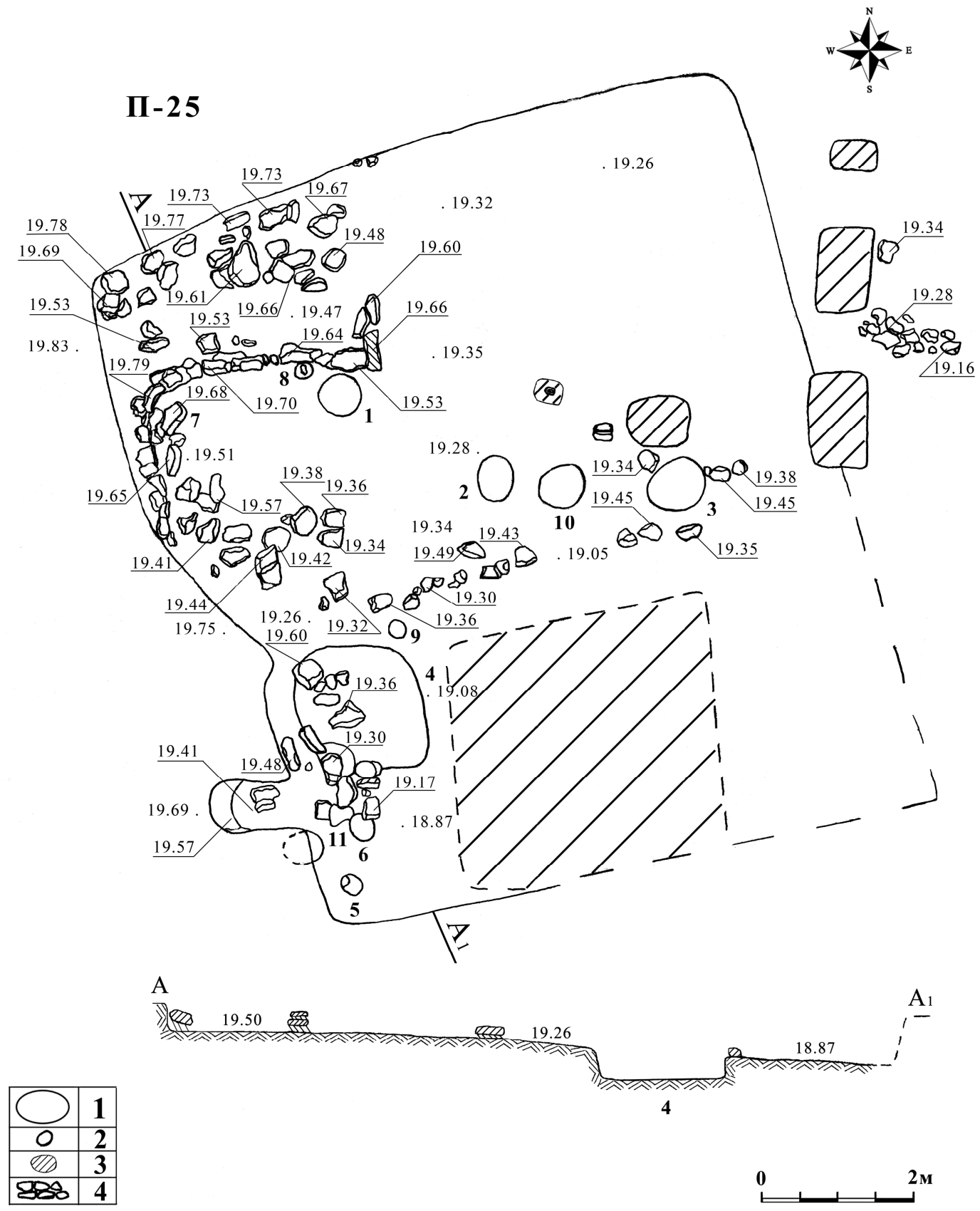

Рис. 2. План приміщення № 25

1 - контури приміщень; 2 - ями; 3 - сучасні ями; 4 - кам'яні кладки.

Серед зафіксованих артефактів (рис. 3; таблиця 1):

1. Фрагменти керамічного посуду (закриті - 40 фр., відкриті 11 фрагментів). Серед посудин можна виділити: горщики різних типів - 29 фр.; банки - 2 фр.; корчаги 3 фр. (1 лощена); келихи - 6 фр. (2 лощені); миски - 9 фр. (1 з вдавлюванням по вінчику); пласкі жаровні - 2 фр. 


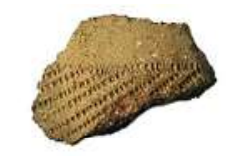

|

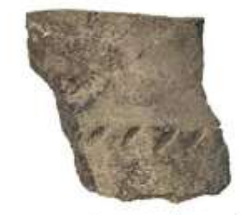

Lumbulum

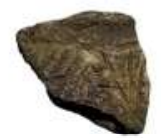

2

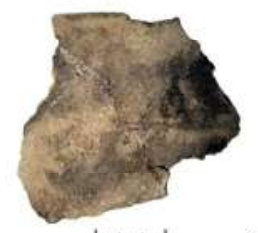

6
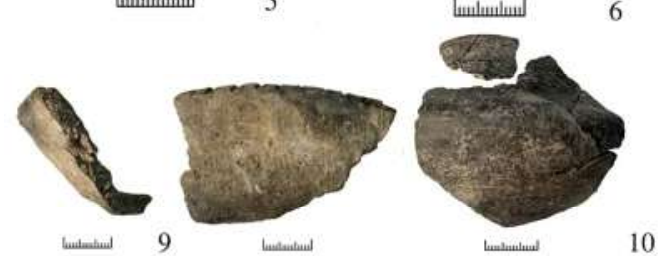

10
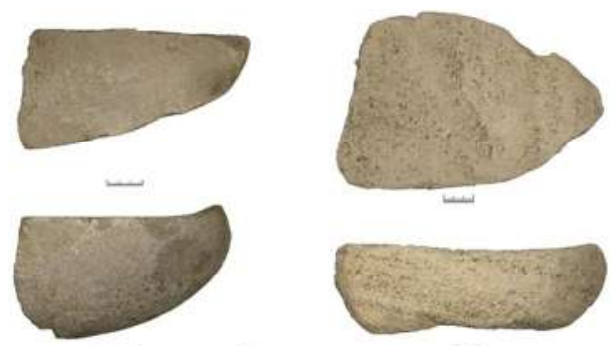

14
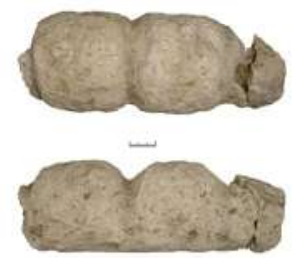

17

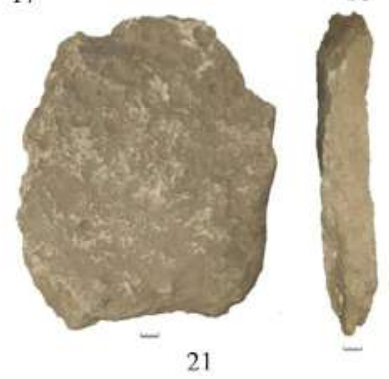

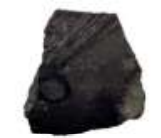

3

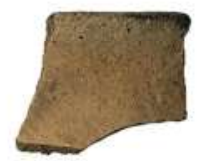

7
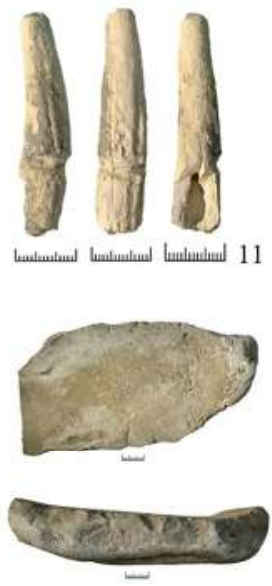

15

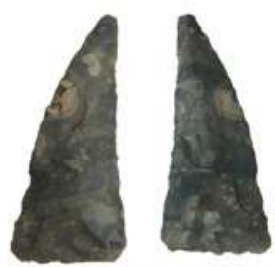

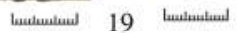
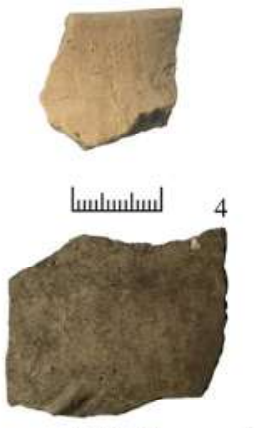

8
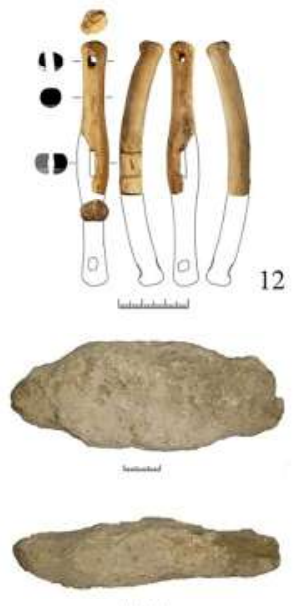

16

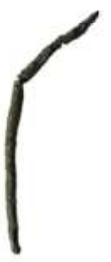

20

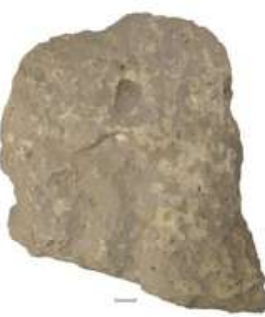

22

Рис. 3. Артефакти з приміщення № 25.

Заповнення приміщення: 1-8; 11-14; 16-20. Заповнення ям приміщення: 9-10; 15; 21-22

1-10: фрагменти керамічного посуду (келихи, горщики, корчага, миска, чаша); 11 - ріг з елементами обробки; 12 - роговий псалій з трьома отворами; 13-15 - кам'яні зернотерки; 16-18 - кам'яні якоря; 19 - кременевий серп;

20 - бронзове шило; 21 - вапнякова плита зі слідами обробки (антропоморфна стела);

22 - вапнякова плита зі слідами обробки (антропоморфна стела, або жертовник). 
Закриті посудини представлені горщиками різних типів, банкоподібними посудинами, корчагами та келихами. Відкриті посудини представлені мисками з прямими відігнутими стінками, пласким денцем великого діаметру (вінчики мисок заокруглені, переважно орнаментовані овальним та округлим вдавлюванням) і пласкими жаровнями, частина жаровень зі сегментно-обрізаним корпусом. Формувальна маса груба, хоча зустрічаються фрагменти посуду з загладженою та лощеною структурою поверхні (корчага та келихи).

Орнаментальні мотиви представлені - пружком (горщик, дві корчаги); пружком зі вдавлюванням (корчага); зубцюватим штампом (два келиха); прокресленими трикутниками з вершинами, опущеними донизу (два келиха); прокресленими лініями у вигляді хрестів (горщик); овальним і косим вдавлюванням (п'ять горщиків, одна миска).

2. Предмети з бронзи, каменю, кістки, рогу та глини (двадцять один екземпляр). Серед них: бронзове шило; кам'яні куранти - 2 екз.; кам'яні зернотерки - 2 екз.; кам'яні ковадла - 2 екз.; кам'яні якоря - 5 екз.; серп з креміння; заготівка для псалія 3 рогу - 1 екз.; псалій з рогу; керамічний диск; таранні кістки з лощеними поверхнями -5 екз.

3. Кістки тварин та риб (сто тринадцять екземплярів) представлені фрагментами кісток великої та дрібної рогатої худоби - 87 фр.; кабана (ікла) - 3 фр.; риби (карпові, щука, сом) - 23 фр.

Усі артефакти, що зафіксовано у заповнені приміщення № 25, є характерними для колекції матеріальних предметів Дикого Саду (рис. 3). Нетиповою знахідкою є кременевий серп, що зафіксовано на рівні підлоги приміщення, біля ями № 3 (рис. 2 ; 3. 19).

Враховуючи характер і структуру заповнення приміщення й особливості глинистих завалів, можливо припустити, що дві стіни приміщення (східна та південна) були глинобитними з домішками середнього та мілкого вапняку. Західна та, частково, північна стіни мали у фундаменті цокольні кам'яні конструкції, що складалася з великих і середніх рваних по слою вапнякових каменів зі слабкими слідами обробки.

Північно-західна кладка - напівапсидної форми, розташована у північнозахідній частині приміщення. Довжина північної частини кладки, витягнутої за віссю 3-С - 3,25 м; західної частини, витягнутої за віссю Північний Схід-Південний Захід - 2,0 м; ширина - від 0,30 м, до 1,75 м, висота - від 0,18 м до 0,45 м. Каміння укладені на земляному розчині, переважно з дотриманням постелисто-ложкової техніки, місцями облицьовано. Східний край північної частини кладки обкладений, перпендикулярно їй, трьома каменями, розташованими на ребро та горизонтально. Північнозахідний край кладки має вигин дуги, який формує напівколо.

Кладка має від 1 до 5 рядів каменів, нижній з яких розташований на гумусовому суглинку. Шви шириною 0,02-0,08 м. У кам'яній конструкції використаний вапняковий бут і плитняк різного розміру $(0,10-0,65 \times 0,15-0,30 \times 0,04-0,15$ м). Каміння розірвані по шару.

Західна частина кладки розташована упритул до західного краю приміщення. На південь від неї, у вигляді півкола, зафіксований ряд із 6-ти каменів, за характером завалу яких можна припустити, що вони складали конструкцію у вигляді сходинок, яка одночасно маркувала один з проходів у приміщення.

Північна частина кладки розташовується упритул до прибудови, яка у північній частині облицьована рядом каменів. Ширина прибудови за віссю Пн-Пд - 1,50 м, до- 
вжина за віссю С-3 - 3,50 м. У північно-східній частині прибудови зафіксований завал каменів. Виходячи з його конструктивних особливостей, можна стверджувати, що північна кладка прибудови була облицьовано-цокольною.

На рівні підлоги нижнього рівня приміщення досліджено 11 ям (рис. 2). Виходячи 3 розмірів та особливостей заповнення ями можна розподілити на господарські (№ 4 та № 11); господарсько-ритуальні (№ 1, 3 та № 10) і стовпові (№ 2, 5, 6, 7, 8, 9).

Яма № 1 (кв. 46, відмітка 19.21 м). Яма розташована у північній частині приміщення, біля кам'яної кладки господарської прибудови.

Розміри ями: $\emptyset-0,7$ м; глибина - 0,9 м; донної частини: Пн-Пд - 0,8 м, 3х-Сх - 0,7 м. Верхнє заповнення: гумус коричневого кольору, вапняковий камінь. Заповнення основної частини ями однорідного кольору (коричневий гумус з домішками суглинку).

На глибині 0,35 м у північній частині ями - мушля равлика, у східній - стінка керамічного горщика, маловиразні фрагменти керамічних стінок і кісток риби.

На глибині 0,5 м у південній частині ями зміна грунту на золистий, темно-сірого кольору. На цьому рівні зафіксовано: вапняковий бут (4 шт.) та фрагмент граніту зі слідами обробки (розтирач?).

На глибині 0,55 м у південній частині ями фрагменти лопатки ВРХ і панцира черепахи.

На глибині 0,6 м золистий грунт змінився на чорний горілий і проявилася забутовка з вапнякового каміння (3 шт).

На глибині 0,8 м у західній частині фрагмент кістки ВРХ.

Всього каменів в ямі 8 шт. Стінки ями глинисті, рівні, плавно переходять у рівне, піщане дно.

Горілий і золистий грунт у нижній частині ями може вказувати на проведення певного ритуалу. Виходячи з цього яма мала господарсько-ритуальне призначення.

Яма № 2 (кв. 43, відмітка 19,15 м). Яма розташована у центральній частині приміщення. Розміри ями: Ø - 0,7 м; глибина - 0,3 м; Ø донної частини - 0,25 м. Верхнє заповнення: гумус коричневого кольору, слабо виразні фрагменти стінок керамічного посуду, мілкий вапняковий бут і мушлі (3 шт.).

На глибині 0,2 м грунт змінюється на гумус сірого кольору з домішками супіски. У заповненні зафіксовано стінка керамічного горщика та кістка ВРХ. Яма округлої форми, звужується до низу. Стінки ями глинисті, плавно переходять у вузьке, рівне дно.

Яма стовпова (центральна опора даху приміщення).

Яма № 3 (кв. 44,61, відмітка 19,13 м). Яма розташована у східній частині приміщення. Розміри ями: Ø- 0,8 м; глибина - 1,4 м; Ø донної частини - 1,20 м. На рівні пола біля ями було знайдено кременевий серп.

Верхнє заповнення: гумус коричневого кольору, рибні кістки, стінки керамічного посуду, мілкий вапняковий бут (2 шт.).

На глибині 0,2 м стінки керамічних горщиків, кістки ВРХ, вапняковий бут (3 шт.).

На глибині 0,4 м скупчення вапнякового каміння (7 шт.). Камені розміщені дугою у західній, східній і південній частинах ями.

На глибині 0,45 м по всій площі ями забутовка продовжується (мілке та середнє вапнякове каміння (всього 17 каменів).

Серед каменів забутовки знаходилася велика вапнякова плита (стела?), яка розташовувалася горизонтально. Розміри плити: висота - 0,34 м; ширина - 0,33 м; товщина - 0,09 м. На плиті зафіксовано сліди обробки поверхні та граней. У верхній час- 
тині штучне овальне заглиблення (0,04×0,03 м), під ним - штучний жолоб (довжина 0,16 м, ширина - 0,02 м), що веде до нижнього краю плити. Вірогідно, це фрагмент верхньої частини антропоморфної стели або жертовника.

На глибині 0,7 м у північній частині ями знайдено ще одну велику вапнякову плиту (висота - 0,31 м; ширина - 0,26 м; товщина - 0,05 м). Грані плити оброблені (ймовірно, антропоморфна стела). Під плитою копито коня (лощило).

На глибині 0,85 м в центрі ями - частина великого горщика (корчаги) та ребро ВРХ зі слідами обробки (лощило?), біля ребра вапняковий камінь.

На глибині 0,9-0,95 м - стулка молюска та стінки керамічного посуду. В північносхідній частині ями - фрагменти миски першого типу, по вінчику орнаментована косими вдавлюваннями, внутрішня частина пропечена, а зовнішня з підпалами. Біля миски - курант коричневого кольору округлої форми з 4-ма робочими поверхнями та 5 вапняковими каменями.

На глибині 1,0 м у східній частині ями - курант округлої форми с 5-ма робочими поверхнями та два астрагала з обробленими поверхнями.

На глибині 1,10 м у східній частині ями - фрагмент пласкої жаровні, у західній частині ями - невеликі вапнякові каміння округлої форми (3 шт.), фрагменти нижньої частини керамічного горщика. Нижче цього рівня каміння у заповненні ями не зустрічаються (загальна кількість каменів - 34 шт.).

На глибині 1,20 м - фрагмент вапнякового обробленого каменю (якір?), у південній частині скупчення лиманної глини зеленого кольору, частини хребта ВРХ і стінка миски.

На глибині 1,30 м скупчення лиманної глини зеленого кольору та вкраплення деревного вугілля.

На глибині 1,40 м, по всій площі дна ями, грунт змінився на сірий золистий 3 вкрапленнями лиманної глини зеленого кольору та фрагменти деревного вугілля.

Стінки ями просушені, глинисті. 3 глибини 0,85 м яма розширюється донизу. Дно рівне, піщане, просушене. Яма господарсько-ритуальна.

Яма № 4 (кв. 35, 36, 38, 39, відмітка 19,08 м). Яма розташована у південнозахідній частині приміщення, біля входу (західна частина ями примикала до західної стінки котловану приміщення). Розміри ями: Пн-Пд -1,8 м; 3x-Cx - 1,60 м; глибина 0,35 м; донна частина: Пн-Пд - 1,7 м; Зх-Сх - 1,45 м. Верхнє заповнення: гумус темносірого кольору. В південній частині яма перекрита двома каменями.

Основне заповнення ями однорідне (коричневий гумус з домішками суглинку) із залишками фрагментів невиразного керамічного посуду, кісток тварин і риби.

На глибині 0,25 м проявилися округлі приямки (можливо, опори для дерев'яних стовпів): у південно-західній частині ями, приямок 4-а (розміри: Ø - 0,15 м; глибина 0,1 м). Заповнення: гумус темно-коричневого кольору з невиразними фрагментами керамічного горщика (вінчик, стінки); у північно-західній частині, приямок 4-б (розміри: $\varnothing-0,15$ м; глибина - 0,1 м). Заповнення: гумус темно-коричневого кольору, курант округлої форми та керамічна стінка горщика.

На глибіні 0,3-0,35 м, у центральній частині ями, зафіксовані невиразні фрагменти керамічного посуду (миска, горщик, вінчик келиха), кістки тварин (BPX, ДРХ) та риби (сом, карпові).

Стінки ями рівні, глинисті, просушені, плавно переходять у рівне, глинисте, просушене дно.

Ймовірно, яма господарського призначення (зберігання продуктів, або інвентарю). 
Яма № 5 (кв. 20-а, 35, відмітка 19,06 м). Яма розташована у південній частині приміщення. Розміри ями: Пн-Півд - 1,7 м; 3x-Сx - 0,35 м; глибина - 0,15 м; Ø донної частини - 0,30 м. У західній частині ями зафіксовано невеликий приямок (Ø- 0,15 м; глибина - 0,08 м). Верхнє заповнення: гумус чорного кольору. Стінки ями рівні, глинисті, просушені, плавно переходять у рівне, глинисте дно. Яма стовпова.

Яма № 6 (кв. 35, відмітка 19,08 м). Яма розташована у південній частині приміщення, біля входу. Розміри ями: Пн-Пд - 0,5 м; 3x-Cx - 0,45 м; глибина - 0,2 м; $\emptyset$ донної частини $-0,35$ м. Верхнє заповнення: гумус темно-коричневого кольору та фрагменти керамічного горщика (вінчик, стінка, денце). Стінки ями рівні, глинисті, просушені, плавно переходять у рівне, глинисте, просушене дно. Яма стовпова.

Яма № 7 (кв. 45, відмітка 19,37 м). Яма розташована у північно-західній частині приміщення, біля кам'яної кладки господарської прибудови. Розміри ями: Пн-Пд 0,5 м; 3x-Cx - 0,4 м; глибина - 0,1 м; донна частина - Пн-Пд - 0,4 м; 3x-Cx - 0,35 м. Верхнє заповнення: гумус світло-коричневого кольору. Яма перекрита вапняковим каменем трапецієподібної форми. У західній частині контур ями заходить під кладку. В північній і південній частинах яма поділена двома невеличкими приямками. Стінки ями глинисті плавно переходять в дно. Яма стовпова.

Яма № 8 (кв. 46, відмітка 19,34 м). Яма розташована в північній частині приміщення, біля кам'яної кладки господарської прибудови. Розміри ями: $\emptyset-0,2$ м; глибина - 0,15 м; Øдонної частини - 0,2 м. Верхнє заповнення: гумус світлокоричневого кольору, 4 вапнякових каменя. Стінки ями глинисті, рівні, плавно переходять у глинисте дно. Яма стовпова.

Яма № 9 (кв. 39, відмітка 19,32 м). Яма розташована у центральній частині приміщення, біля ями № 4. Розміри ями: Ø- 0,2 м; глибина - 0,15 м; Ø донної частини - 0,15 м. Верхнє заповнення: гумус світло-коричневого кольору. Стінки ями глинисті, рівні, просушені, різко переходять у рівне, глинисте дно. Яма стовпова.

Яма № 10 (кв. 44, відмітка 19,34 м). Яма розташована в східній частині приміщення, між ямами № 2 і № 3. Розміри ями: $\emptyset-0,6$ м; глибина - 1,4 м; Ø донної частини - 1,5 м. Верхнє заповнення: гумус чорного кольору, фрагменти кераміки, кісток риби та мушлі равлика.

На глибині 0,35 м у південній частині зафіксовано скупчення мушель равликів (5 шт.).

На глибині 0,4 м грунт заповнення ями змінюється з гумусу чорного на гумус сірого кольору із вкрапленнями фрагментів вугілля (товщина золистого шару - 0,5 м). На глибині 0,7 м у південно-східній частині ями невиразний вапняковий камінь.

На глибині 0,9 м у центральній частині ями глиняна пробка товщиною 0,05 м. Під пробкою, на глибині 0,95 м, грунт заповнення знову змінюється та стає чорного кольору з фрагментами кераміки (стінки горщиків і мисок).

На глибині 1,20 м скупчення фрагментів лощеної чаші чорного кольору.

На глибині 1,30 м, у північній частині ями, плаский вапняковий камінь $(0,2 \times 0,2 \times 0,05 \mathrm{M})$.

На глибині 1,35-1,40 м у східній частині зафіксовані кам'яна зернотерка прямокутної форми, гранітний курант і розтирач човноподібної форми для зерна (обидва 3 кварциту). Стінки ями піщані, різко переходять у рівне, добре просушене піщане дно. Яма господарсько-ритуальна.

Яма № 11 (кв. 35, відмітка 19,20 м). Яма розташована у південній частині приміщення, в борту західної стіни біля входу. Яма витягнута по вісі Зх-Сх. 
Розміри ями: ширина - 0,4 м; висота - 0,3 м (заглиблення від рівня підлоги 0,1 м); Ø донної частини - 0,5 м. Заповнення: гумус чорного кольору, кістка тварини та фрагменти кераміки. На глибині 0,1 м на захід у стіні приміщення, в південній частині, знайдено фрагмент кістки (ДРХ).

На глибині 0,15 м на захід у стіні приміщення зафіксовано два вапнякових каменя та фрагменти керамічних стінок горщиків.

У західній частині, на тій самій глибині (0,15 м), зафіксована кам’яна викладка (15 каменів) і фрагмент миски з орнаментом (по вінчику овальні вдавлювання). Стінки ями глинисті, добре просушені, плавно переходять в дно. Яма господарська.

Отже, серед ям приміщення № 25 - 2 господарських; 3 господарсько-ритуальних; 6 стовпових.

Серед зафіксованих артефактів (рис. 3; таблиця 1):

1. Фрагменти керамічного посуду (закриті - 19 фр., відкриті 8 фрагментів). Серед посудин можна виділити: горщики різних типів - 15 фр.; корчагу; келихи - 3 фр. (1 лощений); чашу (лощена); миски - 6 фр. (2 з вдавлюванням по вінчику); пласку жаровню- 1 фр.

Закриті посудини представлені горщиками різних типів, корчагами та келихами. Відкриті посудини представлені чашами, мисками з прямими відігнутими стінками, пласким донцем великого діаметру (вінчики мисок заокруглені, переважно орнаментовані овальним та округлим вдавлюванням) та пласкими жаровнями, частина жаровень із сегментно-обрізаним корпусом.

Формувальна маса груба, хоча зустрічаються фрагменти посуду із загладженою та лощеною структурою поверхні (чаша та келих). Орнаментальні мотиви представлені овальним вдавлюванням (корчага, дві миски).

2. Предмети з каменю, кістки та глини (дванадцять екземплярів). Серед них: кам'яні куранти - 3 екз.; кам'яні плити антропоморфної форми - 2 екз.; кам'яні зернотерки - 2 екз.; кам'яний якір; лощило з ребра тварини; лощило з копита коня; таранні кістки з лощеними поверхнями - 2 екз.

3. Кістки тварин, риб і мушлі (шістдесят вісім екземплярів) представлені фрагментами кісток великої та дрібної рогатої худоби - 38 фр.; панциром черепахи; риби (карпові, щука, сом) - 18 фр.; мушлі - 11 екз.

Усі артефакти, що зафіксовано у заповнені ям приміщення № 25, є характерними для колекції матеріальних предметів Дикого Саду (таблиця 1, рис. 3).

Отже, приміщення № 25, можна охарактеризувати як злегка заглиблену споруду прямокутної форми, з овальними кутами, довгою віссю витягнутою уздовж річки. Загальна площа приміщення сягає 85,5 м². Три стіни приміщення були глинобитними з домішками середнього та мілкого вапняку (північна, східна та південна), західна та частково північна стіни мали у фундаменті цокольні кам'яні конструкції, що складалися з великих і середніх, рваних по слою, вапнякових каменів зі слабкими слідами обробки, що є характерним як для сабатинівської, так і для білозерської систем домобудівництва.

У північній частині приміщення розташовувалася господарська прибудова (рис. $1 ; 2)$, що є характерним і для інших жител Дикого Саду.

Вхід до приміщення (кв. 25, 35) у формі коридору (ширина 0,7-0,75 м, довжина 1,40-1,45 м) з невеликим нахилом, розташовувався у південно-західному куті. Дах, виходячи з розташування стовпових ям, був односкатним, з нахилом до оборонного рову. Підлога добре утрамбована та промазана глинистим розчином багато разів. 

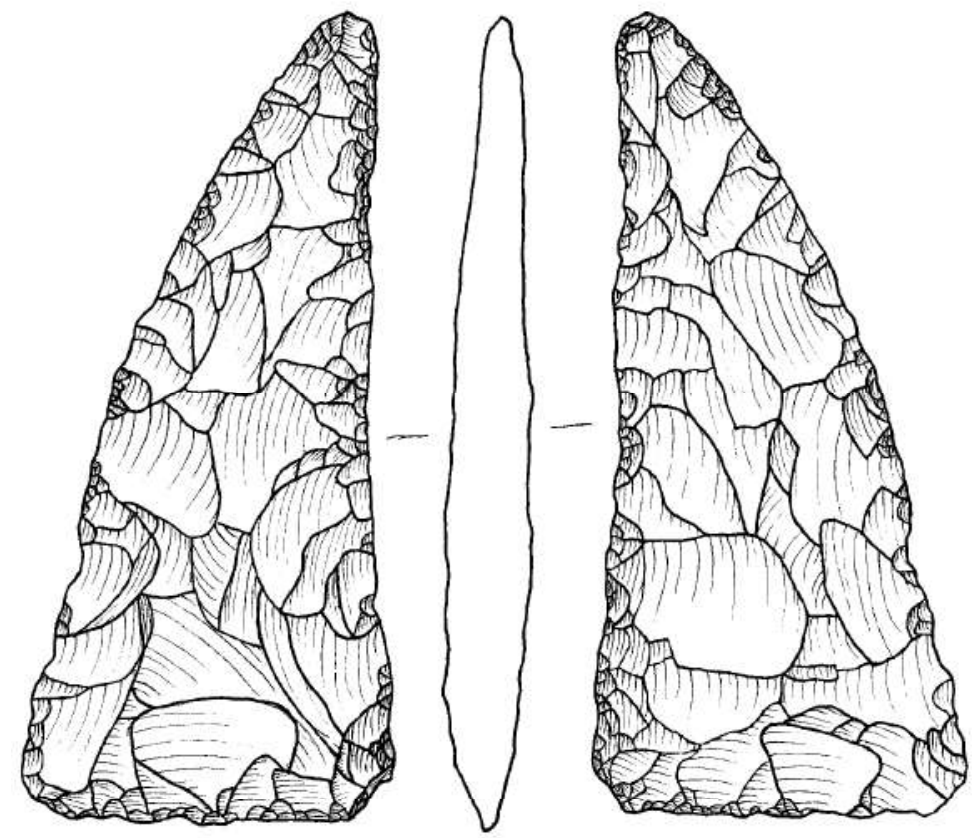

1
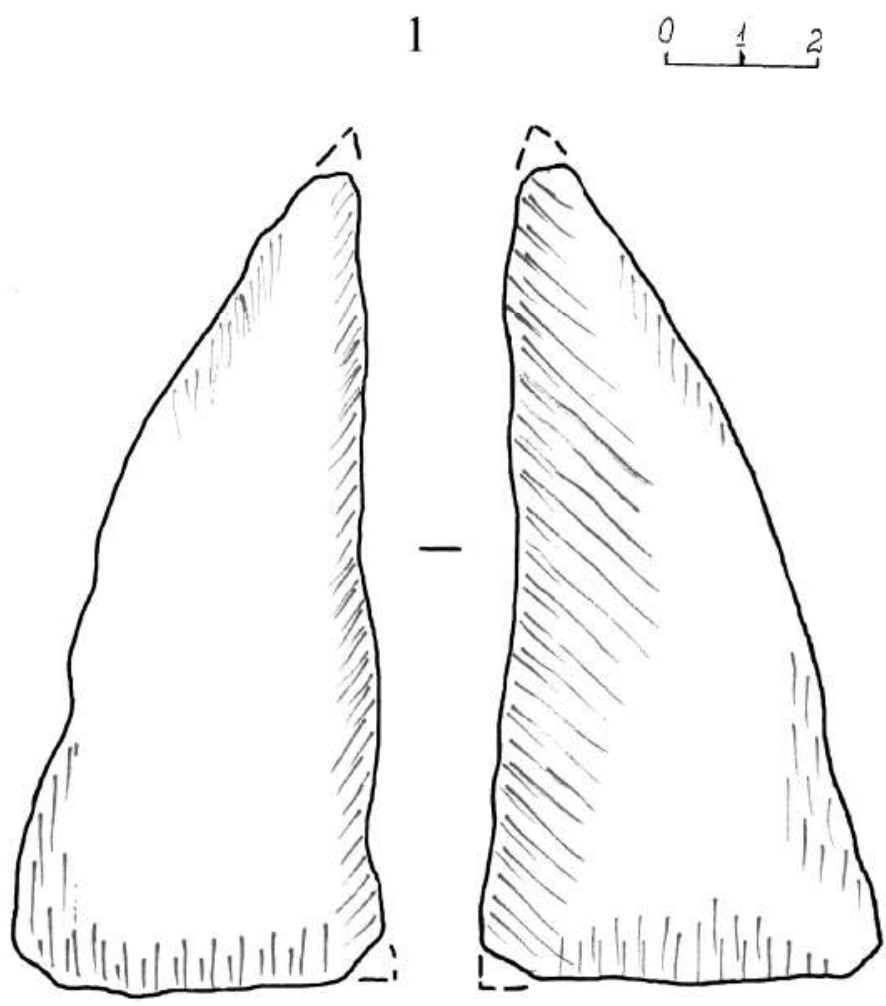

2

Рис. 4. Кременеве знаряддя (1) та ділянки з інтенсивним лиском (2). 
Виходячи з конструктивних особливостей побудови приміщення, характеру та заповнення ям, а також зафіксованих артефактів та екофактів, можна припустити, що воно використовувалося мешканцями городища як житло з господарською спорудою у північній частині зі складною системою багатофункціональних ям (стовпові, господарські, господарсько-ритуальні).

Ймовірно, приміщення побудовано при зародженні життя на території городища й існувало упродовж тривалого часу. Подібні споруди є характерними для пам'яток Північного-Західного Причорномор'я доби пізньої та фінальної бронзи.

Основу зафіксованих матеріальних предметів (рівень підлоги та заповнення ям приміщення), складає керамічний посуд (78 екземплярів), що розподіляється на дві групи: закриті - 59 екземплярів і відкриті - 19 екземплярів (таблиця 1). Основні групи та види посуду з приміщення № 25 характерні для матеріалів городища Дикий Сад і трапляються у матеріалах поселень білозерського часу Північно-Західного Причорномор'я³.

Інші артефакти представлені виробами з рогу, кісток тварин, глини та каміння (таблиця 1). Серед них переважають таранні кістки з обробленою поверхнею та кам'яні якоря, зернотерки та куранти.

Екофакти складаються із залишків кісток, іклів і рогу тварин, кісток риби панцира черепахи та равликів.

Серед найбільш знакових знахідок виокремлюються - роговий псалій, кременевий серп і кам'яні предмети антропоморфної форми (рис. 3.12, 19, 21, 22). Псалії й антропоморфні стели присутні у колекції матеріальних предметів Дикого Саду4. Окремого аналізу, на думку авторів, заслуговує кременевий виріб сірого кольору (перша знахідка подібного характеру на території Дикого Саду) у вигляді неправильного трикутника, розмірами 11,1×5,3×1,1 см, що інтерпретується в археологічній літературі як серп.

Основа серпа пряма. Одна сторона трикутника слабо увігнута. Друга сторона має дещо опуклий обрис. Виготовлений за допомогою техніки біфасіальної обробки 3 плаского уламку або великого масивного відщепу. Знаряддя двобічноопукле, більш великими сколами, що заходять до середини заготівки, задано загальну форму знаряддя, після чого, майже по всьому периметру, нанесена серія більш дрібних сколів, що формують гострі краї виробу. Кути знаряддя дещо заокруглені. Це може бути наслідком цілеспрямованого виготовлення, або гострі кути були зламані у процесі використання, а потім доопрацьовані (рис. 4. 1).

Краї й обидві поверхні знаряддя на різних ділянках мають більший чи менший лиск. Такий лиск може свідчити про те, що цю річ довго носили і/або це сліди полірування у процесі роботи. На різних ділянках, як вже вказано, лиск різної інтенсивності. Найбільш інтенсивний - уздовж краю грані, що злегка увігнута. Причому, на різних поверхнях знаряддя вздовж цієї грані, інтенсивний лиск займає різну площу (на одній поверхні він розташований вздовж краю, на іншій поверхні - заходить до середини виробу). Це, опосередковано, може свідчити про роботу знаряддям під кутом, що характерно для використання в якості серпа. Менш інтенсивний лиск роз-

3 Горбенко К.В. Посуд ділянки «Цитадель» городища Дикий Сад // Археологія. 2018. № 4. С. 28-46; Горбенко К.В. Посуд з рову ділянки «Цитадель» городища Дикий Сад // Археологія. 2019. № 2. C. 19-39.

4 Горбенко К.В. Основные аспекты материальной культуры городища Дикий Сад // Емінак: науковий щоквартальник. 2016. № 4 (16) (жовтень-грудень). Спецвипуск: Forum Olbicum I. Пам’яті В.В. Крапівіної. С. 19-32. 
ташовано на основі й окремих ділянках опуклої грані (рис. 4. 2). У зв’язку з цим постає питання з приводу кріплення та використання даного знаряддя. У літературі зустрічаються різні припущення з приводу кріплення подібних знарядь в оправах 5 , що пов'язані з можливою функцією знарядь. Але, при цьому, потрібно враховувати варіанти ймовірного переоформлення окремих знарядь та їх поліфункціональність. Візуальний огляд і вивчення макрослідів зносу дозволяє припустити декілька варіантів кріплення та використання даного виробу.

Перший варіант кріплення пов'язаний з використанням даного виробу в якості наконечника списа (рис. 5.1). Про можливе таке використання опосередковано може свідчити слабка асиметричність знаряддя вздовж його довгої вісі, а також присутність сколів, що потоншують базальну частину як, наприклад, у наконечників доби енеоліту. Інший варіант кріплення пов'язаний з можливим використанням виробу в якості сокири, клевця чи серпа (рис. 5.2), або серпа чи ножа (рис. 5. 3, 4).

Однак, на наш погляд, використання знаряддя з подібним кріпленням в оправі (рис. $5.2 a, 3,4$ ) в якості серпа $є$ малоймовірним, хоча подібний варіант кріплення для цієї функції зустрічається в археологічній літературі (напр.: С. Разумов 6 ). Справа у тому, що таке кріплення та специфічні рухи, що здійснюються серпом, будуть призводити до постійного виламування знаряддя з оправи. Логічніше для цієї операції подібний виріб було б кріпити в оправу з рогу або щелепи (рис. 6. 2). Крім того, у цих варіантах кріплення та використовування виробу в якості серпа, незрозумілим є поява окремих ділянок з лиском різної інтенсивності на опуклій грані знаряддя.

Більш функціональним, на наш погляд, є дещо інше кріплення (рис.6.1), при якому використовувати це знаряддя в якості серпа i/або ножа було б більш практичним. При цьому кріпленні, також, більш логічно можна пояснити формування на виробі ділянок з різною інтенсивністю лиска.

I, на останнє, знаряддя могли використовувати в якості ножа і/або серпа просто тримаючи його у руці, тим більше, що розмір знаряддя це дозволяє (рис. 6. 3).

Отже, попередній візуальний аналіз форми знаряддя та макрослідів зносу дозволяє припустити, що даний кременевий виріб, найвірогідніше, використовувався в якості серпа, хоча і не відкидається інше його використання. У процесі роботи знаряддя, в залежності від способу використання, утримувалось у руці або кріпилося в оправі з кістки та рогу. Подальший трасологічний аналіз дозволить більш детально прояснити функцію та способи кріплення цього виробу.

Складніше $є$ питання пов'язане з місцем і часом виготовлення знаряддя. Це тема для окремого дослідження. Знайдено воно на пам'ятці білозерської культури, де елементи кремнеобробки не зафіксовані, а в культурному шарі зустрічаються лише поодинокі кременеві вироби. Тому виготовлення цього знаряддя безпосередньо на поселенні Дикий Сад є малоймовірним. Лиск по всіх поверхнях виробу опосередковано свідчить про те, що його певний час транспортували вже у готовому вигляді. Звідки та як довго його пересували - на ці питання відповісти наразі неможливо, так як, наприклад, при візуальному огляді встановлювати навіть місце родовища кременю дещо некоректно.

\footnotetext{
5 Разумов С. Изделия из кремня: изготовление и использование // От бронзы к железу: хозяйство жителей Инкерманской долины (по материалам исследований поселений Уч-Баш и Сахарная Головка) / Э.А. Кравченко, С.А. Горбаненко, Л.В. Горобец, Р.В. Кройтор, С.Н. Разумов, М.С. Сергеева, Е.Ю. Яниш. Киев: ИА НАН Украины, 2016. С. 99-106, рис. 3.2 .5 ${ }^{6}$ Ibidem.
} 


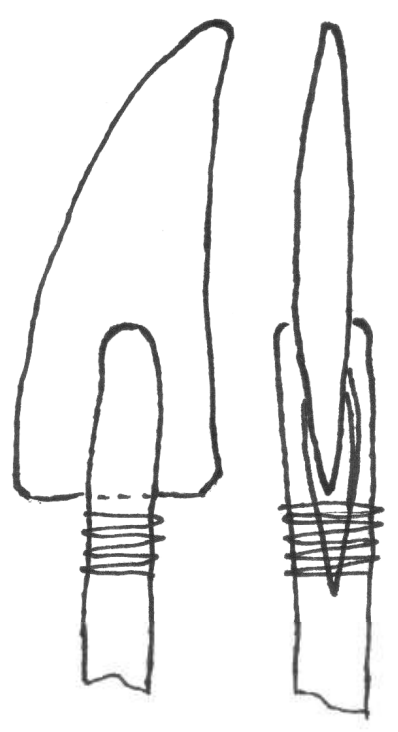

1
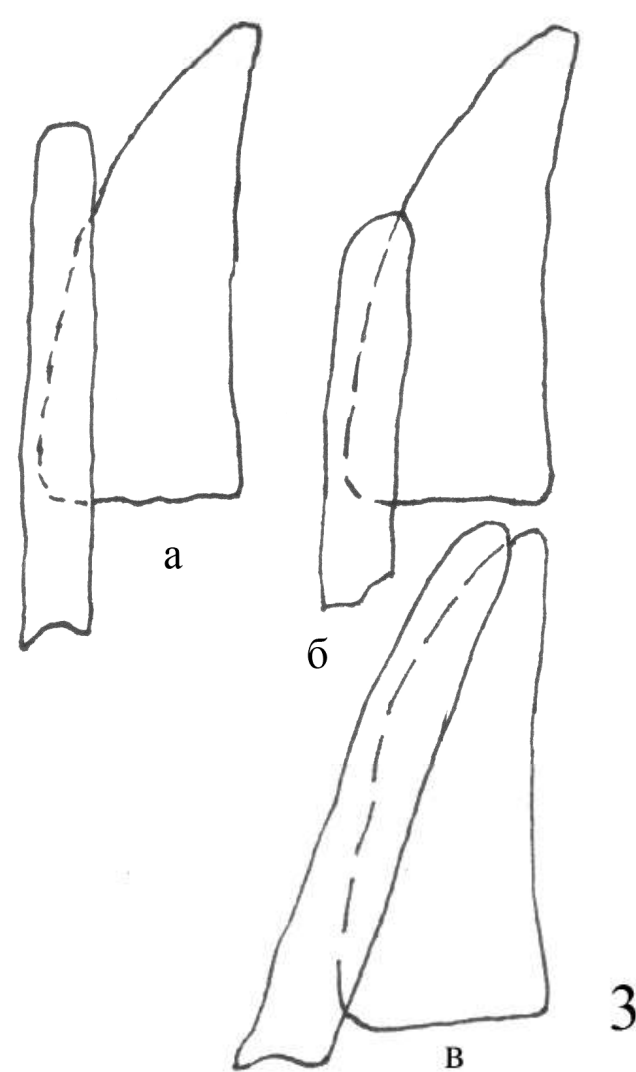

Рис. 5. Варіанти кріплення знаряддя в оправі.

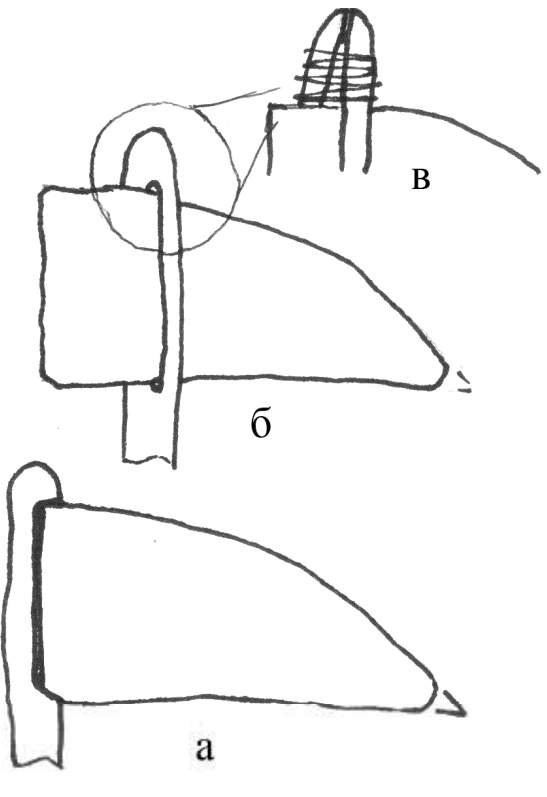

2

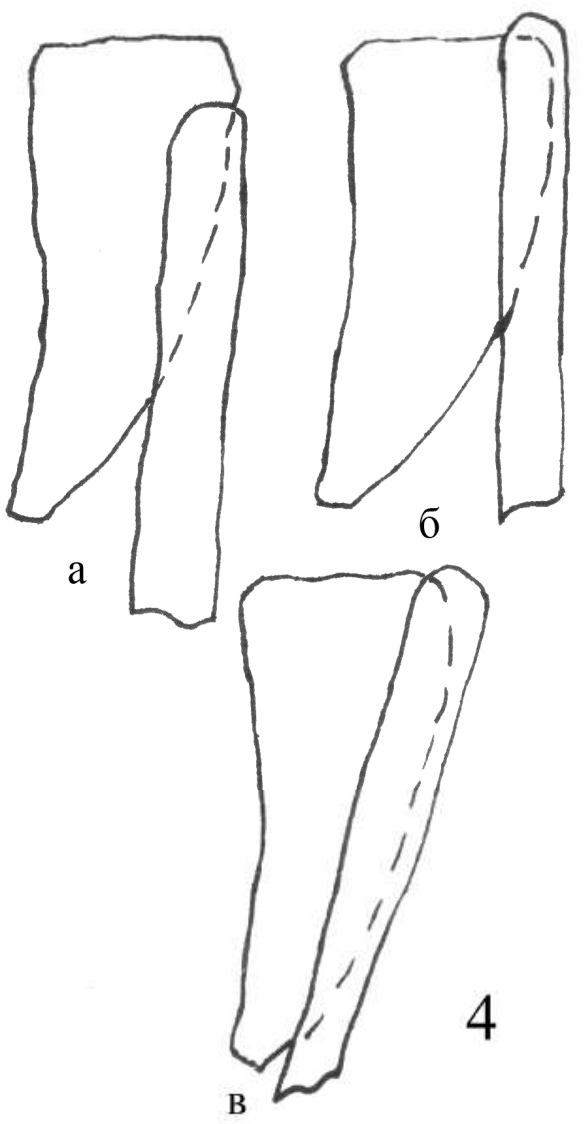




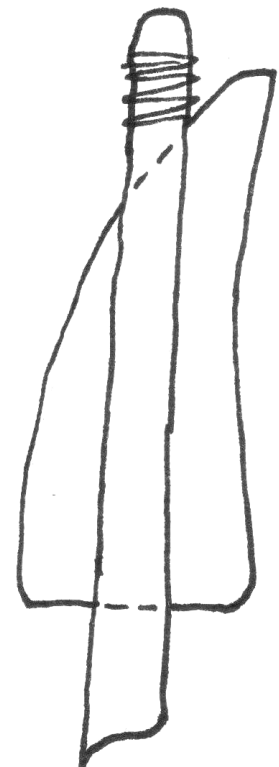

a

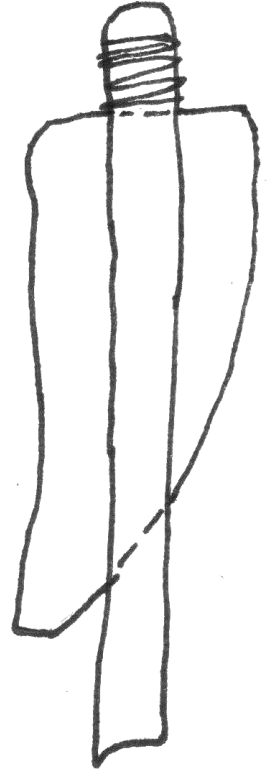

6

1

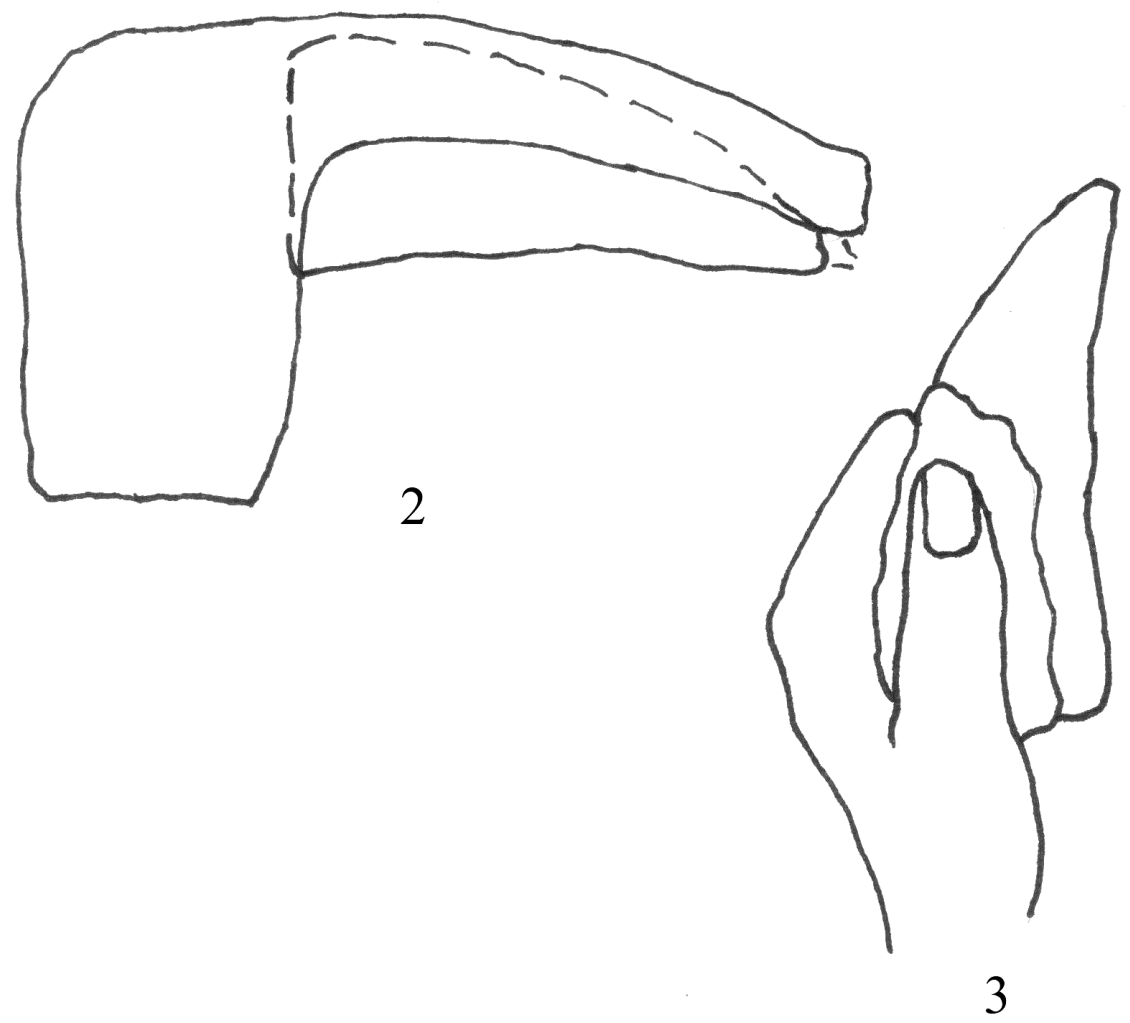

Рис. 6. Варіанти кріплення та використання кременевого знаряддя. 
На пам'ятках білозерської культури зустрічаються двобічнооброблені кременеві знаряддя, що інтерпретуються як серпи. Наприклад, таке знаряддя знайдено на поселенні Балта I7. Схоже знаряддя (уламок?), що також пов'язується з білозерською культурою (підйомний матеріал, с. Ясиново II Любашівського району Одеської області), експонується в Одеському археологічному музеї. Однак, типологічно ці вироби дещо відрізняються від знаряддя, знайденого на городищі Дикий Сад. Вони масивніші (більш товсті) та більш видовжених пропорцій. Їхні леза сильніше увігнуті, а обушки мають сильніше опуклий обрис, що більше робить їх схожими на класичний серп. Єдине, що їх поєднує - техніка двобічної обробки.

За манерою оформлення серп з Дикого Саду більше схожий на біфасіальні серпи, що були знайдені на поселенні пізнього бронзового віку Уч-Баш (Крим)8. Однак, якщо порівнювати форму знарядь, ми також не знаходимо між ними повної відповідності, навіть якщо враховувати різні варіанти їх ймовірного переоформлення. Також, схожі за формою знаряддя (т. зв. «серпи білогрудівського типу») пов'язують 3 пам'ятками білогрудівської культурия.

Але, як і в попередньому випадку, є певні відмінності, але вже у техніці оформлення лез і базальних частин знарядь ${ }^{10}$.

3 іншої сторони, біфасіальна обробка та подібне оформлення з'являється у більш ранні часи енеоліту-ранньої бронзи у вигляді двобічнооброблених наконечників. Таким чином, з'ясувати місце та час виготовлення знаряддя за наявними даними не є можливим. Єдине, що ми поки можемо більш-менш однозначно стверджувати, що це знаряддя виготовлено не на городищі Дикий Сад, а, у різних варіаціях, подібна форма та спосіб виготовлення зустрічається на різних, у культурному відношенні, пам'ятках доби пізньої бронзи.

Отже, археологічні розкопки на території укріпленого поселення Дикий Сад у 2019 р. дозволили дослідити новий археологічний об’єкт - приміщення № 25, охарактеризувати його структуру та характер заповнення ям, проаналізувати комплекс матеріальних речей, зокрема, кременевий серп, як нетиповий предмет для городища. Відкриття нового приміщення дозволило уточнити архітектурну будову «цитаделі» городища, отримати нові артефакти та нові знання про побут мешканців регіону наприкінці II тисячоліття до н.е.

Подяка: Висловлюємо щиру подяку к.і.н. Сергію Разумову та к.і.н. Сергію Лисенку за консультації.

\section{REFERENCES}

Berezanskaia, S.S. (1985). Belogrudovskaia kultura [Belogrudov culture]. Arkheologiia Ukrainskoi SSR, 1, 499-512 [in Russian].

Vanchugov, V.P. (1990). Belozerskie pamiatniki v Severo-Zapadnom Prichernomorie [Belozersky archaeological sites in the Northwest Black Sea Region]. Kiev: Naukova dumka [in Russian].

Gorbenko, K.V. (2016). Osnovnye aspekty materialnoi kultury gorodishcha Dikii Sad [The main aspects of the material culture of the settlements of the Dikii Sad]. Eminak, 4 (16), 19-32 [in Russian].

\footnotetext{
7 Ванчугов В.П. Белозерские памятники в Северо-Западном Причерноморье. Киев: Наукова думка, 1990. С. 102, рис. 39.6.

8 Разумов С. Указ.раб. С. 99-106, рис. 3.2.3.

9 Лысенко С.Д., Шидловский П.С., Литвинова Л.В. Исследования периферии Малополовецкого археологического комплекса в 2007 г. // Археологічні дослідження в Україні 2006-2007 рр. Київ: ИА НАН Украины, 2008. С. 212-216, рис. 2.1.

10 Березанская С.С. Белогрудовская культура // Археология Украинской ССР. Т. 1. Киев: Наукова думка, 1985. С. 499-512, рис. 136.7, 8.
} 
Horbenko, K.V. (2018). Ukriplene poselennia (horodyshche) epokhy finalnoi Bronzy Dykyi Sad u misti Mykolaievi [Fortified settlement (ancient settlement) of the final Bronze Age Dykyi Sad in Mykolaiv]. Kraieznavstvo. Naukovyi zhurnal, 1 (102), 6-20 [in Ukrainian].

Horbenko, K.V. (2018). Posud dilianky «Tsytadel» horodyshcha Dykyi Sad [Utensils of the Citadel section of the Dykyi Sad settlement]. Arkheolohiia, 4, 28-46 [in Ukrainian].

Horbenko, K.V. (2019). Posud z rovu dilianky «Tsytadel» horodyshcha Dykyi Sad [Utensils from the moat of the Citadel section of the Dykyi Sad settlement]. Arkheolohiia, 2, 19-39 [in Ukrainian].

Horbenko, K.V. \& Hoshko, T.Yu. (2010). Metalevi vyroby z poselennia Dykyi Sad [Metal products from the Dykyi Sad settlement]. Arkheolohiia, 1, 97-111 [in Ukrainian].

Horbenko, K.V. \& Pashkevych, H.O. (2010). Paleoetnobotanichni doslidzhennia na terytorii horodyshcha Dykyi Sad [Paleoetnobotanical studies in the territory of the Wild Garden settlement]. Eminak, 1-4 (5), 5-19 [in Ukrainian].

Razumov, S. (2016). Izdeliia iz kremnia: izgotovlenie i ispolzovanie [Flint Products: Production and Use]. In Ot bronzy $k$ zhelezu: hoziaistvo zhytelei Inkermanskoi doliny (po materialam issledovanii poselenii Uch-Bash i Saharnaia Golovka), (pp. 99-106). Kiev: IA NANU [in Russian].

Lysenko, S.D., Shidlovskij, P.S. \& Litvinova, L.V. (2008). Issledovaniia periferii Malopoloveckogo arheologicheskogo kompleksa v $2007 \mathrm{~g}$. [Studies of the periphery of the Malopolovets archaeological complex in 2007]. In Arkheolohichni doslidzhennia v Ukraini 2006-2007 rr., 212-216 [in Russian].

\section{Kyrylo Horbenko}

(Mykolaiv National University named after V. Sukhomlinsky, Mykolaiv, Ukraine)

ORCID: https://orcid.org/0000-0002-0510-3792

\section{Igor Pistruil}

(Odesa Archeological Museum of the National Academy of Sciences of Ukraine, Odesa, Ukraine)

ORCID: https://orcid.org/0000-0002-6193-1963

\section{Structure № 25 at «Dykyi Sad» Settlement}

The settlement of the Final Bronze Age Dykyi Sad (from the late 13th century to the 11th century BCE) is located on a high plateau upon the confluence of the Inhul and South Buh rivers (the historic center of the modern city of Mykolaiv, on the intersection of Naberezhna and Artyleriiska streets). For convenience, «Dykyi Sad» has been divided into three parts: enclosed by the moat Citadel, Suburbs, and Posad, located outside the outward moat. The architectural structures are disposed in lines along the Inhul River and almost side-by-side to each other, forming a single architectural complex. Regular archaeological studies on the territory of «Dykyi Sad» have been conducted over the last thirty years. During these years, residential, utility, and cultic and ritual objects are studied, hundreds of artifacts (pottery, bronze, bone, and lithic objects) are accumulated, and complex analyzes of archaeological materials are carried out.

The paper deals with the constructional features of the structure № 25, which is located on the territory of the settlement Citadel. The architectural composition and construction principles of the structure, as well as the peculiar features of the internal filling of the pits, are characterized. Material objects (pottery, items made of bone, horn, stone, bronze) found in the cultural layer are analyzed. The most indicative findings include horn cheek-piece, flint sickle, and anthropomorphic lithic objects. The flint sickle, which is the first such finding on the territory of «Dykyi Sad», is analyzed in detail. Different variants for mounting the tool into the haft and its usage are offered.

It is found out that structure № 25 was used by the inhabitants of the settlement as a dwelling with an outhouse in the northern part with a complex system of multifunctional pits (for posts, utility, utility and ritual). Probably the structure was built when «Dykyi Sad» was just founded and existed for a long time. Similar structures are characteristic of the sites of the North-West Black Sea region in the Late and Final Bronze Age. 
A major portion of the found material objects (floor level and filling of the structure pits) are pottery (78 items) divided into two groups: closed - 59 items and open - 19 items. The main groups and types of pottery from structure № 25 are typical for the materials of Dykyi Sad settlement and can be found in the materials of Belozersk time settlements in the NorthWest Black Sea region.

Other artifacts are represented by the items made of horn, animal bones, clay, and stone. Among them dominate the talus bones with processing surface, lithic anchors, grain grinders, and upper grinding stones. Ecofacts include the remains of bones, fangs and horns of animals, fish bones, tortoise and snail shells.

In addition, it is determined that the flint sickle from Structure № 25 is somewhat similar to the bifacial sickles found in Uch-Bash (Crimea), the settlement of the Late Bronze Age, and the sickles of the so-called Bilohrudiv type, which are associated with the sites of Bilohrudiv culture. On the other hand, bifacial processing and similar design appear in earlier times of the Eneolithic-Early Bronze Age in the form of bifacially processed projectile points.

Therefore, it is not possible to determine the location and time when the tool is created. The only thing that can be said is that this tool is not made in the settlement of «Dykyi Sad», but, in different variations, the tools of similar shape and method of crafting are found at sites of the Late Bronze Age belonging to different cultures.

Keywords: Final Bronze Age, Belozersk culture, «Dykyi Sad» settlement, material objects, cheek-piece, flint sickle 